КОРИШЋЕЊЕ ЗДРАВСТВЕНЕ ЗАШТИТЕ СТАНОВНИШТВА СРБИЈЕ Маријола Обрадовић ${ }^{1}$, Радмила Поповић², Бојан Митровић ${ }^{3}$, Бранивоје Тимотић ${ }^{4}$, Александар Митровић ${ }^{5}$

\title{
HEALTH CARE USAGE WITH SERBIAN POPULATION
}

Marijola Obradovic, Radmila Popovic, Bojan Mitrovic, Branivoje Timotic, Aleksandar Mitrovic

\section{Сажетак}

Кроз праксу је запажено, а научно доказано дасеупогледуздравствених потреба и коришћења здравствене заштите битно разликују градско и сеоско, мушко и женско, пољопривредно и непољопривредно, образованије и мање образовано, млађе и старије становништво.

Циљ овог рада је да се сагледају особености коришћења здравствене заштите становништва Србије по територијалним деловима Србије, полу, узрасту, типу насеља, образовағу и имовном стағу. У том ичиљу су анализирани подаци анкетног истраживањ које је у више наврата извршио Институт за јавно здравље Србије.

Резултати анализе су показали да здравствену заштиту користи велики проценат становништва Србије. Тако је здравствену заштиту користило 60,4\% деце школског узраста, а 54,2\% одраслог становништва и то знатно више градских него сеоских насеља, жена него мушкараия, старијих него млађих и имућнијих него сиромашнијих, те образованијих него мање образованих становника. Код лекара опште медицине није никада било 2\% школске деце и 1,6\% одраслих. Просечан број посета по становнику био је три, а по школском детету 1,8.

Становници су у великом проценту користили и услуге приватних здравствених установа и то знатно вите у градским насељима, имућнији, жене имлађи становници, те образованији него мање образовани.

\section{Summary}

Through practice it is observed and scientifically proven that in terms of health needs and health care usage, there is a significant difference between urban and rural population, male and female gender, agricultural and non-agricultural, more educated and less educated, younger and older population.

The goal of this research is to analyze the characteristics of the use of health services in Serbia by territorial parts of Serbia, gender, age, type of settlement, education and wealth status. For this purpose, we analyzed data of the survey research that was repeatedly performed by the Institute of Public Health of Serbia.

The analysis results showed the percentage of the population of Serbia that use health care. Thus, $60.4 \%$ of children of school age, and $54.2 \%$ of the adult population had the benefit of health care and the percentage was substantially higher in urban than in rural places, also, there were more women than men, older women than younger, wealthier than poorer and more educated than less educated population. $2 \%$ of school children and $1.6 \%$ of adults have never been examined by a general practitioner. The average number of visits per inhabitant was 3, and per school child 1.8.

$A$ high percentage of the inhabitants used the services of private medical institutions and much more in urban settlements, also these services are more used by wealthier people, women and younger inhabitants and more educated people as well. They choose to go to

\footnotetext{
${ }^{1}$ Мр сц. др Маријола Обрадовић, Завод за здравствену заштиту радника „Железнице Србије“, Београд, Савска 23.

2 Др Радмила Поповић, Општа болница Лозница, Болничка бб.

${ }^{3}$ Др Бојан Митровић, Клиничко болнички центар „Земун“, Земун, Вукова 9.

${ }^{4}$ Проф. др Бранивоје Тимотић, професор социјалне медицине у пензији.

${ }^{5}$ Др Александар Митровић, Клиника за неурохирургију, Клинички центар Србије, Косте Тодоровића 4, Београд.
} 
У приватне здравствене установе одлазе јер нема чекања, особље је љубазније и добијају квалитетнију здравствену заштиту.

Хитну медицинску помоћ користи 4,9\% становника Србије, а специјалистичко консултативну службу 29,7\% са просечно једном посетом по становнику. Стационарну здравствену заштиту је користило 6,6\% становника Србије, знатно више старијег и имућнијег становништва.

Општи је закључак да се и поред свих баријера, здравствена заштита користи у релативно високом нивоу.

Кључне речи: здравствена зачтита, коришћење, становништво. private health institutions because there is no waiting, the staff is friendlier and they receive better health care there.

$4.9 \%$ of the population of Serbia use ambulance services, while specialist and consultant services are used by $20.7 \%$, with an average of one visit per capita. Inpatient health care is used by $6.6 \%$ of Serbia, again it is more used by older and wealthier population.

The general conclusion is that, in spite of all obstacles, there is a relatively high level of health care usage.

Key words: health care, usage, population.

\section{УВОД}

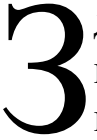

дравствена заштита је организована и свеобухватна делатност друштва на очувању и унапређењу здравља, спречавању, сузбијању и раном откривању болести, повреда и других поремећаја здравља и благовременом и ефикасном лечењу и рехабилитацији. Она је била различита у разним историјским периодима. У првобитној заједници циљ здравствене заштите је био очување способности за лов, обраду земље и борбу са непријатељем. Развојем друштвено-економских односа јављају се сложене и бројне здравствене потребе, па и њихово задовољавање добија сложеније форме..$^{(1,2)}$

Треба разликовати здравствене потребе, захтеве, коришћење здравствене заштите и здравствену потрошњу. Здравствене потребе су поремећај здравља и благостања који захтева услуге здравствене службе и оне су веома разноврсне, комплексне и променљиве у зависности од културног и социо-економског развоја друштва. ${ }^{(3)}$ Све здравствене потребе се не претварају аутоматски у захтеве да се оне задовоље. Превасходни интерес сваког друштва је да се непрепознате потребе претворе у познате, а оне у реално коришћење здравствене заштите, јер је правовремена медицинска интервенција гаранција прекидања природног тока обољења.

Научно је доказано и кроз праксу запажено да се у погледу здравствених потреба и понашања у вези са здрављем битно разликују: градско и сеоско становништво, пољопривредно и непољопривредно, становништво различитог степена образовања, млађе и старије становништво, мушкарци и жене, сиромашнији и богатији итд.

Свака структурна категорија становништва карактерише се специфичним ставовима у вези са здрављем и болешћу и начином односа према здрављу и болести и има специфични морбидитет и морталитет. У том смислу постоје и разлике и у коришћењу здравствене заштите. ${ }^{(4,5)}$

\section{ЦИЛ И МЕТОДЕ РАДА}

Основни циљ рада је сагледавање карактеристика коришћења здравствене заштите становништва Србије. То коришћење је сагледано по полу, узрасту, територијалним деловима Србије, типу насеља, нивоу образовања и имовном стању. 
Реализујући циљ истраживања коришћен је метод анкетног истраживања, тј. анализирани су подаци обимног анкетног истраживања које је у три наврата спровео Институт за јавно здравље Србије.

\section{РЕЗУЛТАТИ И ДИСКУСИЈА}

У табели један су приказани подаци о коришћењу примарне здравствене заштите школске деце. Према тим подацима у Србији свог лекара има 45,6\% школске деце, далеко више у Београду и уопште у градским насељима, затим женски пол и млађи узраст, као и најимућнији у односу на најсиромашније.

Табела 1. Коришћење примарне здравствене заштите у школском диспанзеру.

\begin{tabular}{|c|c|c|c|c|c|c|}
\hline \multirow[t]{2}{*}{ Показатељи } & \multirow{2}{*}{$\begin{array}{l}\text { Имају } \\
\text { свог } \\
\text { лекара }\end{array}$} & \multirow{2}{*}{$\begin{array}{l}\text { Прво се } \\
\text { обраћај } \\
\text { у свом } \\
\text { лекару }\end{array}$} & \multirow{2}{*}{$\begin{array}{l}\text { Посете } \\
\text { лекару } \\
\text { последње } \\
\text { године }\end{array}$} & \multirow{2}{*}{$\begin{array}{l}\text { Никад } \\
\text { нису } \\
\text { били код } \\
\text { лекара }\end{array}$} & \multicolumn{2}{|c|}{ Просечан број посета } \\
\hline & & & & & По детету & $\begin{array}{l}\text { По } \\
\text { кориснику }\end{array}$ \\
\hline Београд & 76,5 & 25,6 & 77,1 & 1,0 & 2,2 & 3,4 \\
\hline Ц. Србија & 36,5 & 28,4 & 52,8 & 3,5 & 1,7 & 3,6 \\
\hline Војводина & 10,6 & 27,8 & 61,5 & 0,9 & 1,8 & 4,0 \\
\hline Србија & 45,6 & 28,5 & 60,4 & 2,0 & 1,8 & 3,5 \\
\hline$\overline{\Gamma р а д ~}$ & 49,4 & 26,4 & 63,4 & 2,2 & 1,9 & 3,8 \\
\hline Село & 40,5 & 31,4 & 56,3 & 1,8 & 1,7 & 3,2 \\
\hline Мушко & 43,6 & 28,4 & 58,7 & 2,4 & 1,6 & 3,0 \\
\hline Женско & 47,6 & 28,6 & 62,0 & 1,7 & 1,9 & 4,0 \\
\hline $7-11$ & 51,5 & 18,0 & 62,3 & 2,5 & 1,8 & 4,1 \\
\hline $12-14$ & 45,6 & 25,3 & 61,4 & 1,5 & 1,7 & 3,0 \\
\hline $15-19$ год. & 40,3 & 40,2 & 58,0 & 1,9 & 1,9 & 3,6 \\
\hline Најсиром. & 31,8 & 29,8 & 45,7 & 4,5 & 1,2 & 2,9 \\
\hline Најимућ. & 60,8 & 24,0 & 67,1 & 0,9 & 1,9 & 3,8 \\
\hline
\end{tabular}

У последњих дванаест месеци у Србији се $60,4 \%$ деце јавило лекару у диспанзер, највише у Београду и другим градским насељима, те више женске него мушке и најимућнијих него најсиромашнијих. Проценат одласка код лекара опада са узрастом деце, јер је и здравствено стање тих узраста знатно боље.

У Србији код лекара није никада било $2 \%$, највише најсиромашније деце.
Просечан број посета по детету је био 1,8, а по кориснику 3,5. Слични показатељи су и у појединим територијалним деловима Србије.

Подаци табеле два показују да је у Србији највише посета школске деце било због болести и повреда $(57,3 \%)$ и због контроле здравља $(30,6 \%)$, док су остали разлози далеко ређи. 
Табела 2. Разлози посете лекару школске деце.

\begin{tabular}{|l|l|l|l|l|l|l|}
\hline \multirow{2}{*}{ Показатељи } & \multicolumn{5}{l}{ Главни разлози посете (у \%) } \\
\cline { 2 - 7 } & $\begin{array}{l}\text { Контрола } \\
\text { здавља }\end{array}$ & $\begin{array}{l}\text { Болест, } \\
\text { повреда }\end{array}$ & $\begin{array}{l}\text { Пропи- } \\
\text { сивање } \\
\text { лека }\end{array}$ & $\begin{array}{l}\text { Добијање } \\
\text { оправда- } \\
\text { ьа }\end{array}$ & $\begin{array}{l}\text { Добијање } \\
\text { упута }\end{array}$ & Друго \\
\hline Београд & 38,6 & 49,2 & 1,7 & 6,3 & 1,9 & 0,8 \\
\hline Ц. Србија & 27,5 & 58,9 & 2,0 & 4,3 & 1,7 & 0,6 \\
\hline Војводина & 31,8 & 52,3 & 1,9 & 3,5 & 1,6 & 0,6 \\
\hline Србија & 30,6 & 57,3 & 1,9 & 4,4 & 1,8 & 0,8 \\
\hline Град & 30,3 & 57,9 & 2,1 & 4,2 & 1,7 & 0,6 \\
\hline Село & 31,1 & 56,5 & 1,7 & 4,9 & 1,9 & 0,6 \\
\hline Мушко & 29,7 & 57,0 & 2,0 & 4,9 & 1,8 & 0,8 \\
\hline Женско & 31,6 & 57,5 & 1,9 & 4,0 & 1,8 & 0,4 \\
\hline $7-11$ & 30,8 & 59,5 & 1,8 & 2,1 & 1,2 & 0,7 \\
\hline $12-14$ & 34,1 & 56,4 & 0,8 & 3,4 & 1,8 & 0,7 \\
\hline $15-19$ год. & 28,1 & 55,9 & 2,8 & 7,3 & 2,4 & 0,4 \\
\hline Најсиром. & 30,5 & 54,5 & 2,0 & 3,1 & 2,5 & 0,2 \\
\hline Најимућ. & 39,7 & 50,3 & 1,5 & 4,5 & 1,9 & 0,5 \\
\hline
\end{tabular}

На табели три су показани подаци о коришћењу примарне здравствене заштите одраслог становништва.

Табела 3. Коришћење примарне здравствене заштите одраслог становништва (у\%).

\begin{tabular}{|c|c|c|c|c|c|c|c|c|}
\hline \multirow[t]{2}{*}{ Показатељи } & \multirow{2}{*}{$\begin{array}{l}\text { Има } \\
\text { свог } \\
\text { лека- } \\
\text { ра }\end{array}$} & \multirow{2}{*}{$\begin{array}{l}\text { Прво } \\
\text { се } \\
\text { јавља } \\
\text { лекару } \\
\text { оп.мед. }\end{array}$} & \multirow{2}{*}{$\begin{array}{l}\text { После- } \\
\text { дње } \\
\text { год. } \\
\text { нису } \\
\text { били } \\
\text { код } \\
\text { лекара }\end{array}$} & \multirow{2}{*}{$\begin{array}{l}\text { Нису } \\
\text { никад } \\
\text { били } \\
\text { код } \\
\text { лекара }\end{array}$} & \multicolumn{2}{|c|}{$\begin{array}{l}\text { Просечна } \\
\text { посета }\end{array}$} & \multirow{2}{*}{$\begin{array}{l}\text { Разлог } \\
\text { последње } \\
\text { посете } \\
\text { контр. } \\
\text { здравља }\end{array}$} & \multirow{2}{*}{$\begin{array}{l}\text { Чека- } \\
\text { ли на } \\
\text { дијаг. } \\
\text { пре- } \\
\text { глед } \\
\text { више } \\
\text { од } \\
\text { месец } \\
\text { дана }\end{array}$} \\
\hline & & & & & $\begin{array}{l}\text { По } \\
\text { стано- } \\
\text { внику }\end{array}$ & $\begin{array}{l}\text { По } \\
\text { кори- } \\
\text { снику }\end{array}$ & & \\
\hline Београд & 76,9 & 69,0 & 57,4 & 0,8 & 3,1 & 5,4 & 26,5 & 5,7 \\
\hline Ц. Србија & 39,9 & 63,2 & 52,5 & 2,2 & 3,1 & 5,9 & 26,5 & 3,9 \\
\hline Војводина & 48,7 & 61,7 & 54,7 & 1,2 & 2,8 & 5,2 & 23,2 & 6,3 \\
\hline Србија & 50,6 & 64,6 & 54,2 & 1,6 & 3,0 & 5,6 & 25,3 & 5,0 \\
\hline$\overline{\Gamma р а д ~}$ & 56,0 & 65,0 & 55,1 & 1,9 & 3,1 & 5,6 & 26,6 & 5,4 \\
\hline Село & 43,6 & 64,1 & 53,0 & 1,3 & 3,0 & 5,6 & 23,5 & 4,3 \\
\hline Мушко & 46,9 & 63,9 & 49,9 & 2,1 & 2,7 & 5,5 & 27,1 & 4,6 \\
\hline Женско & 54,9 & 65,4 & 59,0 & 1,1 & 3,4 & 5,7 & 23,7 & 5,3 \\
\hline $20-34$ & 39,2 & 60,3 & 41,6 & 2,5 & 1,2 & 2,9 & 27,1 & 2,0 \\
\hline $35-44$ & 47,3 & 64,2 & 46,8 & 1,8 & 1,9 & 4,0 & 27,0 & 4,0 \\
\hline $45-54$ & 53,0 & 64,5 & 51,0 & 1,1 & 2,8 & 5,6 & 28,1 & 5,4 \\
\hline $55-64$ & 57,6 & 68,4 & 62,8 & 1,5 & 4,4 & 7,0 & 25,7 & 6,9 \\
\hline $65-74$ & 60,3 & 70,7 & 69,2 & 1,2 & 5,0 & 7,3 & 21,5 & 6,5 \\
\hline $75+$ год. & 55,8 & 61,1 & 69,8 & 0,9 & 4,9 & 7,0 & 22,0 & 3,6 \\
\hline Најсиром. & 39,2 & 61,1 & 50,8 & 3,0 & 3,2 & 6,2 & 20,7 & 3,8 \\
\hline Најимућ. & 62,9 & 65,0 & 53,0 & 1,4 & 2,5 & 4,8 & 32,4 & 5,7 \\
\hline
\end{tabular}


Према подацима табеле три 50,6\% одраслог становништва Србије има свог лекара, највише Београђана и уопште становника градских насеља, затим жена, старијих особа и најимућнијих становника.

У случају потребе одрасли становници Србије се прво обраћају лекару опште медицине $(64,6 \%)$. У последњих дванаест месеци код лекара је било $54,2 \%$ становника Србије, из знатно више градских насеља, жена, старијих и имућнијих. Код лекара није никада било 1,6\% становника Србије, нешто више мушкараца него жена, млађих и најсиромашнијих становника. Просечно је по једном становнику долазило три посете, а по кориснику 5,6.

Табела 4. Врсте пружених услуга у дому здравља (у\%).

\begin{tabular}{|c|c|c|c|c|c|}
\hline \multirow[t]{2}{*}{ Услуге } & \multirow[t]{2}{*}{ Време } & \multicolumn{4}{|c|}{ Територија } \\
\hline & & Београд & $\begin{array}{l}\text { Војводи- } \\
\text { на }\end{array}$ & Ц.Србија & Србија \\
\hline \multirow{4}{*}{$\begin{array}{ll}\text { Мерење } \\
\text { притиска }\end{array}$} & Никад & 17,5 & 11,5 & 13,9 & 15,0 \\
\hline & Пре 5 год. & 13,1 & 13,6 & 13,5 & 13,4 \\
\hline & $1-5$ год. & 23,2 & 24,5 & 23,1 & 22,8 \\
\hline & Задње године & 46,3 & 50,4 & 49,4 & 48,8 \\
\hline \multirow[t]{4}{*}{ Одређивање ШУК } & Никад & 23,1 & 22,0 & 26,5 & 26,8 \\
\hline & Пре 5 год. & 15,0 & 18,0 & 17,2 & 17,2 \\
\hline & $1-5$ год. & 26,8 & 27,2 & 25,2 & 25,2 \\
\hline & Задње године & 35,1 & 32,8 & 31,1 & 30,8 \\
\hline \multirow{4}{*}{$\begin{array}{l}\text { Одређивање } \\
\text { масноће у крви }\end{array}$} & Никад & 25,6 & 26,0 & 29,9 & 30,3 \\
\hline & Пре 5 год. & 14,7 & 17,6 & 17,3 & 17,1 \\
\hline & $1-5$ год. & 26,5 & 26,0 & 24,3 & 24,3 \\
\hline & Задње године & 33,2 & 30,4 & 28,5 & 28,3 \\
\hline \multirow{4}{*}{$\begin{array}{l}\text { Хемоглобин у } \\
\text { крви }\end{array}$} & Никад & 18,7 & 19,8 & 21,1 & 22,6 \\
\hline & Пре 5 год. & 17,2 & 19,4 & 18,9 & 18,9 \\
\hline & $1-5$ год. & 28,0 & 27,7 & 27,2 & 26,5 \\
\hline & Задње године & 36,1 & 33,0 & 32,7 & 32,0 \\
\hline \multirow[t]{4}{*}{ Анализа мокраће } & Никад & 14.7 & 11,9 & 15,2 & 16,1 \\
\hline & Пре 5 год. & 17,6 & 20,9 & 19,9 & 20,1 \\
\hline & $1-5$ год. & 29,3 & 30,4 & 28,9 & 28,6 \\
\hline & Задње године & 38,5 & 36,8 & 35,9 & 35,2 \\
\hline \multirow{4}{*}{$\begin{array}{ll}\text { Мерење телесне } \\
\text { мace }\end{array}$} & Никад & 35,0 & 25,9 & 35,5 & 35,0 \\
\hline & Пре 5 год. & 21,6 & 25,4 & 22,5 & 22,7 \\
\hline & $1-5$ год. & 21,0 & 22,8 & 21,2 & 20,9 \\
\hline & Задње године & 22,4 & 26,0 & 20,8 & 21,5 \\
\hline \multirow[t]{4}{*}{ Контрола вида } & Никад & 22,8 & 20,9 & 28,9 & 28,0 \\
\hline & Пре 5 год. & 25,1 & 29,8 & 26,3 & 26,2 \\
\hline & $1-5$ год. & 28,8 & 29,3 & 25,6 & 26,2 \\
\hline & Задње године & 23,4 & 20,0 & 19,1 & 19,7 \\
\hline \multirow[t]{4}{*}{ Контрола слуха } & Никад & 37,8 & 35,6 & 42,3 & 41,9 \\
\hline & Пре 5 год. & 24,8 & 29,7 & 24,4 & 24,9 \\
\hline & $1-5$ год. & 22,7 & 22,1 & 20,7 & 20,8 \\
\hline & Задње године & 14,8 & 12,6 & 12,6 & 12,3 \\
\hline
\end{tabular}


Из података табеле четири произилази да у коришћењу појединих услуга у дому здравља постоје веома значајне разлике по појединим територијалним деловима Србије. Треба запазити да је највећи број услуга пружен у току претходне године, што је вероватно одраз и сећање анкетираних особа. Такође, треба запазити да велики проценат анкетираних није никада користио наведене услуге, неке чак и 41,9\%.

У табели пет су приказане поједине услуге пружене у дому здравља по полу. Ови подаци показују да постоје значајне разлике у коришћењу појединих здравствених услуга од стране мушкараца и жена.

Табела 5. Врсте пружених услуга у дому здравља по полу.

\begin{tabular}{|c|c|c|c|c|c|c|c|}
\hline \multirow[t]{2}{*}{ Услуге } & \multirow[t]{2}{*}{ Време } & \multicolumn{3}{|c|}{ Број услуга } & \multicolumn{3}{|l|}{$\%$} \\
\hline & & M & Ж & Свега & $\mathrm{M}$ & Ж & Свега \\
\hline \multirow{4}{*}{$\begin{array}{l}\text { Мерење крвног } \\
\text { притиска }\end{array}$} & Никад & 897 & 792 & 1689 & 16,9 & 13,3 & 15,0 \\
\hline & Пре 5 год. & 852 & 652 & 1504 & 16,1 & 10,9 & 13,4 \\
\hline & $1-5$ год. & 1261 & 1297 & 2558 & 23,8 & 21,8 & 22,8 \\
\hline & Последње године & 2284 & 3202 & 5486 & 43,2 & 54,0 & 48,8 \\
\hline \multirow{4}{*}{$\begin{array}{l}\text { Одређивање } \\
\text { ШУК }\end{array}$} & Никад & 1543 & 1461 & 3004 & 29,2 & 24,6 & 26,8 \\
\hline & Пре 5 год. & 1066 & 868 & 1934 & 20,2 & 14,6 & 17,2 \\
\hline & $1-5$ год. & 1260 & 1567 & 2827 & 23,8 & 26,3 & 25,2 \\
\hline & Последње године & 1414 & 2045 & 3459 & 26,8 & 34,5 & 30,8 \\
\hline \multirow{4}{*}{$\begin{array}{l}\text { Одређивање } \\
\text { масноће у крви }\end{array}$} & Никад & 1683 & 1715 & 3398 & 31,8 & 28,9 & 30,3 \\
\hline & Пре 5 год. & 1036 & 878 & 1914 & 19,6 & 14,8 & 17,1 \\
\hline & $1-5$ год. & 1243 & 1484 & 2727 & 23,5 & 25,0 & 24,3 \\
\hline & Последње године & 1320 & 1853 & 3173 & 25,1 & 31,3 & 28,3 \\
\hline \multirow{4}{*}{$\begin{array}{l}\text { Хемоглобин } \\
\text { крви }\end{array}$} & Никад & 1371 & 1163 & 2534 & 25,9 & 19,6 & 22,6 \\
\hline & Пре 5 год. & 1165 & 955 & 2120 & 22,0 & 16,4 & 18,9 \\
\hline & $1-5$ год. & 1320 & 1655 & 2975 & 24,9 & 27,9 & 26,5 \\
\hline & Последње године & 1429 & 2160 & 3589 & 27,2 & 36,4 & 32,0 \\
\hline \multirow{4}{*}{$\begin{array}{l}\text { Анализа } \\
\text { мокраће }\end{array}$} & Никад & 1027 & 784 & 1811 & 19,4 & 13,2 & 16,1 \\
\hline & Пре 5 год. & 1258 & 1000 & 2258 & 23,8 & 16,8 & 20,1 \\
\hline & $1-5$ год. & 1458 & 1750 & 3208 & 27,7 & 29,5 & 28,6 \\
\hline & Последње године & 1544 & 2402 & 3946 & 29,1 & 40,5 & 35,2 \\
\hline \multirow{4}{*}{$\begin{array}{l}\text { Мерење телесне } \\
\text { масе }\end{array}$} & Никад & 1817 & 2094 & 3911 & 34,5 & 35,4 & 35,0 \\
\hline & Пре 5 год. & 1341 & 1196 & 2537 & 25,4 & 20,2 & 22,7 \\
\hline & $1-5$ год. & 1068 & 1265 & 2333 & 20,3 & 21,4 & 20,9 \\
\hline & Последње године & 1042 & 1362 & 2404 & 19,8 & 23,0 & 21,4 \\
\hline \multirow[t]{4}{*}{ Контрола вида } & Никад & 1384 & 1756 & 3140 & 26,2 & 29,6 & 27,9 \\
\hline & Пре 5 год. & 1448 & 1487 & 2935 & 27,4 & 25,1 & 26,2 \\
\hline & $1-5$ год. & 1418 & 1516 & 2934 & 26,9 & 25,5 & 26,2 \\
\hline & Последње године & 1033 & 1174 & 2207 & 19,5 & 19,8 & 19,7 \\
\hline \multirow[t]{4}{*}{ Контрола слуха } & Никад & 1910 & 2776 & 4686 & 36,3 & 46,9 & 41,9 \\
\hline & Пре 5 год. & 1458 & 1330 & 2788 & 27,7 & 22,5 & 23,9 \\
\hline & $1-5$ год. & 1187 & 1143 & 2330 & 22,1 & 19,3 & 20,8 \\
\hline & Последње године & 712 & 664 & 1376 & 13,9 & 11,3 & 13,5 \\
\hline
\end{tabular}


Подаци табеле шест показују да постоје значајне разлике у коришћењу здравствене заштите појединих добних група становника. То коришћење углавном расте са узрастом.

Табела 6. Структура пружених услуга у дому здравља по времену пружања и добним групама.

\begin{tabular}{|c|c|c|c|c|c|c|c|}
\hline \multirow[t]{2}{*}{ Услуге } & \multirow[t]{2}{*}{ Време } & \multicolumn{6}{|c|}{ Добне групе } \\
\hline & & $20-34$ & $35-44$ & $45-54$ & $55-64$ & $65+$ & Укупно \\
\hline \multirow{4}{*}{$\begin{array}{l}\text { Мерење } \\
\text { крвног } \\
\text { притиска }\end{array}$} & Никад & 24,9 & 17,0 & 13,3 & 7,3 & 6,0 & 15,0 \\
\hline & Пре 5 год. & 12,8 & 16,0 & 13,6 & 12,7 & 11,0 & 13,4 \\
\hline & $1-5$ год. & 28,6 & 24,0 & 21,2 & 20,8 & 16,0 & 22,8 \\
\hline & Последње године & 33,7 & 43,0 & 51,9 & 59,3 & 67,0 & 48,8 \\
\hline \multirow{4}{*}{$\begin{array}{l}\text { Одређивање } \\
\text { ШУК }\end{array}$} & Никад & 39,6 & 29,0 & 24,3 & 17,5 & 14,0 & 26,8 \\
\hline & Пре 5 год. & 13,2 & 19,0 & 18,6 & 18,4 & 18,0 & 17,2 \\
\hline & $1-5$ год. & 26,2 & 25,0 & 25,0 & 25,9 & 23,0 & 25,2 \\
\hline & Последње године & 21,0 & 27,0 & 32,1 & 38,2 & 45,0 & 30,8 \\
\hline \multirow{4}{*}{$\begin{array}{l}\text { Одређивање } \\
\text { масноће у } \\
\text { крви }\end{array}$} & Никад & 45,1 & 33,0 & 26,9 & 18,9 & 17,0 & 30,3 \\
\hline & Пре 5 год. & 12,4 & 18,0 & 18,4 & 19,7 & 19,0 & 17,1 \\
\hline & $1-5$ год. & 23,9 & 24,0 & 24,2 & 26,0 & 23,0 & 24,3 \\
\hline & Последње године & 18,6 & 25,0 & 30,5 & 35,4 & 41,0 & 28,3 \\
\hline \multirow{4}{*}{$\begin{array}{l}\text { Хемоглобин у } \\
\text { крви }\end{array}$} & Никад & 30,4 & 24,0 & 20,7 & 17,0 & 15,0 & 22,6 \\
\hline & Пре 5 год. & 15,7 & 20,0 & 19,7 & 20,2 & 20,0 & 18,9 \\
\hline & $1-5$ год. & 28,2 & 27,0 & 26,4 & 26,0 & 24,0 & 26,5 \\
\hline & Последње године & 25,7 & 29,0 & 33,2 & 36,7 & 41,0 & 32,0 \\
\hline \multirow{4}{*}{$\begin{array}{l}\text { Анализа } \\
\text { мокраће }\end{array}$} & Никад & 20,3 & 17,0 & 15,6 & 12,6 & 11,0 & 16,1 \\
\hline & Пре 5 год. & 18,1 & 23,0 & 21,0 & 20,4 & 19,0 & 20,1 \\
\hline & $1-5$ год. & 32,8 & 29,0 & 27,4 & 27,0 & 24,0 & 28,6 \\
\hline & Последње године & 28,9 & 35,0 & 36,0 & 40,0 & 46,0 & 35,2 \\
\hline \multirow{4}{*}{$\begin{array}{l}\text { Мерење } \\
\text { телесне масе }\end{array}$} & Никад & 30,0 & 34,0 & 39,1 & 37,4 & 37,0 & 35,0 \\
\hline & Пре 5 год. & 20,1 & 25,0 & 22,0 & 21,3 & 25,0 & 22,7 \\
\hline & $1-5$ год. & 26,7 & 20,0 & 17,7 & 19,6 & 17,0 & 20,9 \\
\hline & Последње године & 23,2 & 21,0 & 21,2 & 21,7 & 21,0 & 21,5 \\
\hline \multirow[t]{4}{*}{ Контрола вида } & Никад & 32,4 & 33,0 & 27,1 & 21,6 & 21,0 & 28,0 \\
\hline & Пре 5 год. & 24,0 & 29,0 & 22,3 & 28,0 & 28,0 & 26,2 \\
\hline & $1-5$ год. & 27,4 & 21,0 & 26,9 & 28,9 & 26,0 & 26,2 \\
\hline & Последње године & 16,2 & 17,0 & 23,3 & 21,5 & 25,0 & 19,6 \\
\hline \multirow{4}{*}{$\begin{array}{l}\text { Контрола } \\
\text { слуха }\end{array}$} & Никад & 42,7 & 43,0 & 45,0 & 40,6 & 37,0 & 41,9 \\
\hline & Пре 5 год. & 22,8 & 27,0 & 22,5 & 26,1 & 26,0 & 23,9 \\
\hline & $1-5$ год. & 23,3 & 18,0 & 20,3 & 21,3 & 19,0 & 20,8 \\
\hline & Последње године & 11,2 & 12,0 & 12,2 & 12,0 & 8,0 & 13,4 \\
\hline
\end{tabular}

Према подацима табеле седам становници Србије у добром проценту користе и услуге приватних лекара и то знатно више становници Београда и уопште градских насеља, затим женско становништво, млађи узраст, образованије и имућније становништво. 
Табела 7. Коришћење услуга приватне праксе (\%).

\begin{tabular}{|l|l|l|l|l|l|l|l|}
\hline \multirow{2}{*}{ Показатељи } & \multicolumn{3}{l|}{ Услуге приватног } & \multicolumn{3}{l|}{ Разлози посете } \\
\cline { 2 - 9 } & $\begin{array}{l}\text { Лек. } \\
\text { О.П. }\end{array}$ & $\begin{array}{l}\text { Стом- } \\
\text { атолог }\end{array}$ & $\begin{array}{l}\text { Гин- } \\
\text { еколог }\end{array}$ & $\begin{array}{l}\text { Нема } \\
\text { чекања }\end{array}$ & $\begin{array}{l}\text { Квал. } \\
\text { рад }\end{array}$ & $\begin{array}{l}\text { Љуба- } \\
\text { зност }\end{array}$ & $\begin{array}{l}\text { Број } \\
\text { анкет. }\end{array}$ \\
\hline Београд & 29,5 & 19,7 & 7,7 & 71,3 & 56,8 & 42,1 & 949 \\
\hline Ц. Србија & 15,1 & 7,2 & 5,5 & 61,9 & 49,7 & 35,9 & 772 \\
\hline Војводина & 19,5 & 8,5 & 7,5 & 66,0 & 47,0 & 30,8 & 1122 \\
\hline Србија & 19,4 & 10,3 & 6,5 & 66,5 & 51,9 & 37,0 & 2843 \\
\hline Град & 22,5 & 12,7 & 7,2 & 67,0 & 54,2 & 37,8 & 1876 \\
\hline Село & 15,2 & 7,1 & 5,5 & 65,6 & 47,4 & 35,3 & 967 \\
\hline Мушко & 15,7 & 8,7 & & 66,2 & 53,3 & 32,6 & 1216 \\
\hline Женско & 23,4 & 12,0 & 6,5 & 66,8 & 50,9 & 40,2 & 1627 \\
\hline $20-34$ & 24,5 & 16,3 & 13,8 & 68,4 & 61,6 & 43,1 & 895 \\
\hline $35-44$ & 23,0 & 14,9 & 8,4 & 64,8 & 55,7 & 40,7 & 562 \\
\hline $45-54$ & 18,4 & 9,3 & 5,0 & 66,6 & 46,8 & 36,0 & 509 \\
\hline 55-64 & 17,7 & 7,5 & 2,0 & 68,2 & 44,3 & 31,3 & 395 \\
\hline 65 - 74 & 14,7 & 4,1 & 0,6 & 65,0 & 42,9 & 29,5 & 325 \\
\hline $75+$ год. & 11,4 & 2,5 & 0,1 & 61,1 & 37,1 & 21,8 & 157 \\
\hline Основно образ. & 11,0 & 3,0 & 2,5 & & & & \\
\hline Средње образ. & 21,7 & 12,7 & 8,4 & & & & \\
\hline Више образовање & 31,9 & 20,3 & 12,2 & & & & \\
\hline Најсиромашнији & 8,9 & 3,1 & 1,8 & 58,9 & 40,8 & 27,5 & 271 \\
\hline Најимућнији & 31,8 & 20,5 & 11,0 & 70,0 & 55,4 & 39,2 & 931 \\
\hline
\end{tabular}

Што се тиче разлога коришћења услуга приватних лекара и стоматолога, такође постоје разлике, али мање изражене.
Коришћење специјалистичке службе и хитне медицинске помоћи (ХМП) у последњој години приказано је на табели број осам.

Табела 8. Коришћење специјалистичке службе и хитне медиџинке помоћи у претходној години.

\begin{tabular}{|l|l|l|l|l|l|l|l|l|}
\hline \multirow{2}{*}{ Показатељи } & \multicolumn{9}{|l|}{ Били код специјалисте } & \multicolumn{2}{l|}{$\begin{array}{l}\text { Просечно } \\
\text { посета }\end{array}$} & \multicolumn{2}{l|}{$\begin{array}{l}\text { Користили } \\
\text { ХМП }\end{array}$} \\
\cline { 2 - 10 } & Број & $\%$ & $\begin{array}{l}\text { Не } \\
\text { због } \\
\text { плаћ. }\end{array}$ & $\begin{array}{l}\text { Чека- } \\
\text { ли } \\
\text { преко } \\
30 \\
\text { мин. }\end{array}$ & $\begin{array}{l}\text { Пта- } \\
\text { новн. } \\
\text { но ко- }\end{array}$ & $\begin{array}{l}\text { По } \\
\text { рисн. }\end{array}$ & $\begin{array}{l}\text { Мин. } \\
\text { чекали }\end{array}$ & \\
\hline Београд & 1058 & 33,1 & 0,8 & 9,0 & 1,0 & 2,9 & 5,3 & 36,4 \\
\hline Ц. Србија & 2141 & 39,4 & 3,7 & 4,2 & 1,0 & 3,6 & 4,3 & 21,3 \\
\hline Војводина & 1113 & 28,9 & 3,7 & 8,9 & 0,9 & 3,0 & 5,9 & 21,1 \\
\hline Србија & 4313 & 39,7 & 3,0 & 6,4 & 1,0 & 3,3 & 4,9 & 25,2 \\
\hline Град & 2597 & 31,5 & 2,1 & 7,8 & 1,0 & 3,3 & 6,3 & 22,8 \\
\hline Село & 1716 & 27,3 & 4,1 & 4,2 & 0,9 & 3,2 & 3,2 & 32,5 \\
\hline Мушко & 2152 & 28,2 & 2,6 & 5,8 & 0,9 & 3,2 & 5,0 & 22,8 \\
\hline Женско & 2161 & 31,4 & 3,4 & 6,9 & 1,0 & 3,3 & 4,9 & 27,8 \\
\hline
\end{tabular}




\begin{tabular}{|l|l|l|l|l|l|l|l|l|}
\hline $20-34$ & 626 & 17,3 & 1,0 & 2,6 & 0,5 & 2,8 & 2,0 & 21,6 \\
\hline $35-44$ & 592 & 24,4 & 1,9 & 4,0 & 0,7 & 2,8 & 3,2 & 25,9 \\
\hline $45-54$ & 809 & 29,8 & 4,1 & 6,4 & 1,1 & 3,6 & 4,9 & 27,6 \\
\hline $55-64$ & 854 & 38,4 & 3,9 & 7,7 & 1,3 & 3,4 & 4,7 & 27,6 \\
\hline $65-74$ & 907 & 41,6 & 4,6 & 8,5 & 1,5 & 3,5 & 7,3 & 28,7 \\
\hline $75+$ год. & 524 & 39,1 & 4,1 & 7,6 & 1,3 & 3,1 & 12,6 & 19,8 \\
\hline Најсиромашнији & 766 & 26,1 & 8,1 & 4,9 & 0,9 & 3,6 & 5,2 & 31,7 \\
\hline Најимућнији & 889 & 30,6 & 0,7 & 8,1 & 0,9 & 3,1 & 5,1 & 27,8 \\
\hline
\end{tabular}

Подаци табеле осам показују да је 29,7\% становника Србије било код лекара специјалисте у претходној години, нешто више Београђана и уопште становника градских насеља, те жена него мушкараца, становника старијих узраста, као и најимућнијих него најсиромашнијих. Просечно је по становнику долазила по око једна посета лекару специјалисти, а око три по кориснику. На специјалистички преглед је чекало више од месец дана 6,4\%.

Хитну помоћ је користило 4,9\% становника Србије, више градских него сеоских насеља, старијих него млађих. На долазак екипе хитне помоћи просечно чекање је износило око 25 минута.

Болничку здравствену заштиту у последњој години је користило у Србији 6,6\% становништва, знатно више старијег и имућнијег становништва (табела 9). Скоро $3 \%$ је чекало на пријем у болницу више од месец дана. Око 79\% је било задовољно исходом болничког лечења, нешто више становника Београда и уопште градских насеља, мушкараца него жена, имућнијих него сиромашнијих и старијих него млађих.

Табела 9. Коришћење болничке здравствене заштите.

\begin{tabular}{|c|c|c|c|c|c|}
\hline \multirow[t]{2}{*}{ Показатељи } & \multicolumn{2}{|c|}{ Лечено болесника } & \multirow{2}{*}{$\begin{array}{l}\text { Просечан } \\
\text { број хоспи- } \\
\text { тализација }\end{array}$} & \multirow{2}{*}{$\begin{array}{l}\text { Чекали на } \\
\text { пријем } \\
\text { дуже } \quad \text { од } \\
\text { месец дана }\end{array}$} & \multirow{2}{*}{$\begin{array}{l}\text { Задовољни } \\
\text { исходом } \\
\text { лечења }\end{array}$} \\
\hline & Број & $\%$ & & & \\
\hline Београд & 224 & 7,0 & 1,2 & 6,1 & 80,4 \\
\hline Ц. Србија & 482 & 6,6 & 1,4 & 1,2 & 78,2 \\
\hline Војводина & 257 & 6,6 & 1,4 & 2,8 & 79,4 \\
\hline Србија & 962 & 6,6 & 1,3 & 2,7 & 79,1 \\
\hline$\overline{\text { Град }}$ & 556 & 6,7 & 1,3 & 2,4 & 81,5 \\
\hline Село & 406 & 6,5 & 1,4 & 3,1 & 75,7 \\
\hline Мушко & 507 & 6,7 & 1,3 & 2,8 & 80,1 \\
\hline Женско & 455 & 6,6 & 1,4 & 2,6 & 77,9 \\
\hline $20-34$ & 124 & 3,4 & 1,3 & 0,8 & 73,8 \\
\hline $35-44$ & 96 & 4,0 & 1,2 & 0,0 & 78,3 \\
\hline $45-54$ & 177 & 6,5 & 1,4 & 3,3 & 77,9 \\
\hline $55-64$ & 181 & 8,2 & 1,3 & 5,3 & 77,5 \\
\hline $65-74$ & 215 & 9,9 & 1,4 & 4,4 & 81,2 \\
\hline $75+$ год. & 168 & 12,5 & 1,3 & 0,0 & 83,5 \\
\hline Најсиромашнији & 219 & 7,5 & 1,5 & 0,8 & 78,8 \\
\hline Најимућнији & 154 & 5,3 & 1,3 & 0,0 & 80,7 \\
\hline
\end{tabular}




\section{ЗАКЉУЧАК}

Здравствену заштиту користи веома висок проценат становништва. Тако је диспанзерску здравствену заштиту користило $60,4 \%$ школске деце Србије, и то знатно више градских него сеоских насеља, женске него мушке деце и најимућније него најсиромашније деце, док са узрастом деце коришћење опада. Код лекара није никада било само 2\% школске деце Србије и то највише најсиромашније. Просечно је на свако дете долазило по 1,8 посета.

Посете лекару у школском диспанзеру су биле најчешће због болести и повреда $(57,3 \%)$ и контроле здравља $(30,6 \%)$, а остали разлози су били далеко ређи.

Одрасло становништво (20 и више година) Србије нешто ређе користи примарну здравствену заштиту $(54,2 \%)$ и то знатно више градских него сеоских насеља, жена него мушкараца и имућнијих него сиромашнијих. Код лекара није никада било 1,6\% становника Србије. Просечно по становнику је било три посете.

При коришћењу примарне здравствене заштите постоје значајне разлике по појединим територијалним деловима Србије, као и по полу и узрасту корисника - расте са узрастом.
Поред коришћења здравствене заштите у државним здравственим установама становништво у великом проценту користи и услуге приватних здравствених установа, и то знатно више из градских насеља, имућнијих и образованијих становника, те млађих и жена. У приватне здравствене установе одлазе због тога што нема чекања, квалитетнији је рад, особље љубазније итд.

Становништво у великом проценту користи и специјалистичко консултативну здравствену заштиту $(29,7 \%)$ у Србији, знатно више градских насеља, женског, старијег и имућнијег становништва. Просечно на сваког становника је долазила по једна посета неком лекару специјалисти. На преглед је чекало дуже од месец дана 6,4\% становника Србије, а 3\% није користило због плаћања услуга.

Хитну медицинску помоћ је користило $4,9 \%$ становника Србије, а просечно се чекало на екипу 25 минута.

Стационарну здравствену заштиту је користило 6,6\% становника Србије, знатно више старијег и имућнијег. Скоро $3 \%$ је чекало на пријем у болницу дуже од 30 дана. Болничким лечењем је било задовољно око $79 \%$ лечених.

\section{ЛИТЕРАТУРА}

1. Тимотић Б. и сар.: Социјална медицина, Веларта, Београд, 2000.

2. Тимотић Б.: Увод у медицину, Elit medica, Београд, 2004.

3. Тимотић Б., Јањић М.: Примарна здравствена заштита, Elit medica, Београд, 2004.

4. Обрадовић М.: Узроци и импликације промена у потребама и коришћењу стоматолошке здравствене заштите становништва Србије од 1951. до 1999. године. Докторска дисертација, Универзитет у Крагујевцу, Крагујевац, 2001 .

5. Перуновић П. и сар.:

Економскофинансијске могућности коришћења здравствене заштите становника Србије, Здравствена заштита, 2009; 38/2: 47-52.

Контакт: Мр сц. др Маријола Обрадовић, Завод за здравствену заштиту радника „Железнице Србије“, Београд, Савска 23. 